\title{
RT-PCR Detection of Equine Arteritis Virus from Various Samples of an Experimentally Infected Pregnant Mare
}

\author{
Shigeo SUGITA*, Hiroshi IMAGAWA, Ryuichi WADA and Yoshio FUKUNAGA \\ Epizootic Research Station (Tochigi), Equine Research Institute, Japan Racing Association, 1400-4 Shiba, \\ Kokubunjimachi, Shimotsuga-gun, Tochigi 329-04, Japan
}

Various clinical and tissue materials derived from an experimentally infected mare were examined for the equine arteritis virus (EAV) by the RT-PCR method. For the reverse transcriptional step, a specific primer (R1 primer) and random (nonspecific) 9-mers primer were used. The specific 292 bp band could be detected clearly with the random primer, but not the specific primer from clinical and various autopsy samples of the pregnant mare and aborted fetus. The sensitivity to detect 7 strains of EAV by RT-PCR with the random primer was tested. The detection limit of Bibuna and Vienna strains of EAV was about $100 \mathrm{PFU}$, although that of other strains, Bucyrus, modified Bucyrus, $84 K Y$-A1, Red Mile and Wroclaw ranged from 1 to 10 PFU. By our RT-PCR method, EAV could be detected within 1 day and could be obtained directly from a urine sample, from which the virus was difficult to isolate without pretreatment due to toxicity in cell culture.

Key words: PCR detection, diagnosis, equine arteritis virus (EAV), random primer
J. Equine Sci.

Vol. 8, No. 2

pp. 29-33, 1997
Equine viral arteritis (EVA) is a specific contagious disease of horses and occurs world-wide. It has never occurred in Japan and has not been found by serological studies [11]. At present, serological diagnosis by the serum neutralization test is carried out on all imported horses at the animal quarantine to prevent the invasion of EAV. Furthermore, the virus isolation in cell culture is conducted for the virological diagnosis of EAV. The isolation and identification of EAV by cell culture demands a period of at least two to three weeks and the EAV sometimes is not isolated when the wild strain of EAV does not adapt to the cell line [6, 13, 17]. Considering these problems, establishment of a highly sensitive diagnosis method that can detect the existence of EAV quickly and accurately is very important. Therefore, we studied the detection of EAV by the RTPCR method from various materials of the experimentally infected pregnant mare with EAV.

This article was submitted September 17, 1996 and was accepted March 28, 1997.

*corresponding author.

\section{Materials and Methods}

Virus strain

We used the Bucyrus strain of $\operatorname{EAV}[7,9]$, for experimental infection in a pregnant mare. For the RTPCR experiment, we used the Bucyrus strain, modified Bucyrus strain [8, 16], 84KY-A1 strain [18], Red Mile strain [17], Vienna strain [2], Bibuna strain [3] and Wroclaw strain $[14,15]$. EHV-1 was used as a negative control [19].

Collection of clinical and autopsy materials from an experimentally infected mare

A Thoroughbred, 20-year-old, pregnant mare at 7 months gestation was intranasally inoculated with the Bucyrus strain of EAV at a titer of $5 \times 10^{6} \mathrm{PFU}$ as described previously [10]. When the mare showed clinical EAV-induced abortion at 12 days after inoculation, it was euthanized and the tissues were collected from the aborted fetus and mare as described previously [10].

Isolation and titration of EAV

EAV was isolated using RK-13 and Vero cells by the 
method as described previously [10]. The isolated virus was identified by the indirect fluorescence antibody method [11]. EAV titration was done using RK-13 cells by the method previously described [12].

\section{RNA extraction}

After addition of $500 \mu \mathrm{l}$ of RNA zolB ${ }^{\mathrm{TM}}$ (Biotex Laboratories, Inc., USA) to $100 \mu \mathrm{l}$ tissue sample, $50 \mu \mathrm{l}$ of chloroform: isoamylalchohol (24:1) was added, vortexed for $15 \mathrm{sec}$ and the mixture was incubated for 5 min on ice. After centrifugation for $15 \mathrm{~min}$ at 12,000 $\mathrm{rpm}$, the supernatant was transferred to a fresh tube. An equal volume of chloroform: isoamylalchohol (24:1) was added to the sample, which was then centrifugated and the supernatant was transferred to a fresh tube. After addition of an equal volume of isopropanol, the sample was incubated for $20 \mathrm{~min}$ on ice. The RNA pellet was recovered by centrifugation for $20 \mathrm{~min}$ at $12,000 \mathrm{rpm}$. The precipitated pellet was rinsed with $70 \%$ ethanol, dried and dissolved in $30 \mu \mathrm{l} \mathrm{TE}$.

\section{Primers}

A pair of primers was designed based on conserved regions of the $\mathrm{M}$ gene alignment of $\operatorname{EAV}[19,20]$. The sequences of the primers are as follows: F2 primer (M gene 151-173; ${ }^{5}$ TTAGCAGCTTATATTTGGTTTGT ${ }^{3}$ ) and R1 primer (M gene $442-425 ;{ }^{5}$ GGCCTGCGGACGTGATCG $\left.^{3}\right)$.

\section{$R T-P C R$}

Reverse transcription reaction mixture consisted of 4 $\mu \mathrm{l}$ of $25 \mathrm{mM} \mathrm{MgCl}_{2}, 2 \mu \mathrm{l}$ of $10 \times$ RNA PCR buffer $(100$ $\mathrm{mM}$ Tris- $\mathrm{HCl} \mathrm{pH} 8.3,500 \mathrm{mM} \mathrm{KCl}), 8 \mu \mathrm{l}$ of dNTP Mixture (containing each $2.5 \mathrm{mM}$ dNTP), $0.5 \mu \mathrm{l}$ of RNase free $\mathrm{H}_{2} \mathrm{O}, 0.5 \mu \mathrm{l}$ of RNase inhibitor (TaKaRa, Japan; 40 Unit/ $\mu \mathrm{l}$ ), $1 \mu \mathrm{l}$ of AMV reverse transcriptase XL (Life Sciences Ltd, USA; $5 \mathrm{U} / \mu \mathrm{l}), 1 \mu \mathrm{l}$ of random 9-mers oligonucleotides $(50 \mathrm{pmol} / \mu \mathrm{l})$ and $3 \mu \mathrm{l}$ of purified RNA sample were added into a fresh tube on ice in this order. $\mathrm{R} 1$ primer $(1 \mu \mathrm{l}$ of $20 \mu \mathrm{M})$ was also used instead of random 9-mers oligonucleotides as the specific primer in the reverse transcription step. In this case $1 \mu$ of pure RNase-free water was added at the subsequent PCR step instead of $\mathrm{R} 1$ primer. The mixture was then incubated at $30^{\circ} \mathrm{C}$ for $10 \mathrm{~min}, 42^{\circ} \mathrm{C}$ for $20 \mathrm{~min}$ and $99^{\circ} \mathrm{C}$ for $5 \mathrm{~min}$ to inactivate the reverse transcriptase.

PCR reaction mixture contained $6 \mu \mathrm{l}$ of $25 \mathrm{mM} \mathrm{MgCl}_{2}$, $8 \mu \mathrm{l}$ of $10 \times$ RNA PCR buffer, $63.5 \mu \mathrm{l}$ of $\mathrm{H}_{2} \mathrm{O}, 1 \mu \mathrm{l}$ of 20 $\mathrm{pmol} / \mu \mathrm{l} \mathrm{F} 2$ primer, $1 \mu \mathrm{l}$ of $20 \mathrm{pmol} / \mu \mathrm{l} \mathrm{R} 1$ primer, $0.5 \mu \mathrm{l}$ of TaKaRa Taq ( $5 \mathrm{U} / \mu \mathrm{l})$ and $20 \mu \mathrm{l}$ of the above reverse transcription reaction mixture added in this order into a fresh tube. The thermal cycling profile was $95^{\circ} \mathrm{C}$ for 2 min, followed by 50 cycles of $94^{\circ} \mathrm{C}$ for $30 \mathrm{sec}, 60^{\circ} \mathrm{C}$ for $30 \mathrm{sec}$ and $72^{\circ} \mathrm{C}$ for $90 \mathrm{sec}$, and an additional incubation at $72^{\circ} \mathrm{C}$ for $5 \mathrm{~min}$.

\section{Densitographic analysis of the RT-PCR band.}

The PCR product was applied to the $2.0 \%$ agarose gel (NuSieve 3:1 agarose, FMC BioProducts) in TBE buffer with $0.5 \mathrm{mg}$ ethidium bromide/litter. After electrophoresis, the DNA band was measured at 254 $\mathrm{nm}$ by the ATTO Densitograph system, Japan, using a CCD camera and Power Macintosh 7100/80AV. Denstitographic analysis was done by ATTO's pattern analyzing program for Mac version 3.02.

\section{Results}

The difference between specific primer and random (nonspecific) primer at the reverse step of RT-PCR was compared using autopsy samples collected from the aborted mare and fetus after exposure to the Bucyrus strain of EAV (Fig. 1). When the specific primer was used, the amplified band became a smear and the 292 bp PCR product predicted with F2 and R1 primers was difficult to detect. On the contrary, when the random primer was used, the $292 \mathrm{bp}$ specific band could be detected. Especially in the urine sample, the specific band appeared as a smear when the specific primer was used. Furthermore, we found a nonspecific band larger than the 292 bp predicted in the liver sample.

Table 1 shows the results of the RT-PCR using the random primer and virus isolation in cell cultures to detect EAV from various clinical and autopsy samples. The EAV was detected by the RT-PCR from all samples, from which the EAV was positively isolated in cell cultures. Also, the PCR band was weak in the liver and myocardium samples, from which the virus was isolated after the second passage in cell cultures. Furthermore, RT-PCR revealed no band from the feces and serum samples, from which the virus was not isolated. From the urine sample, the virus was isolated only after dialysis, because the urine was toxic to the cell culture, while by the RT-PCR the band appeared using only $100 \mu \mathrm{l}$ of fresh urine sample.

Figure 2 shows the density of the EAV-specific band by gel electrophoresis provided as a result of PCR with the modified Bucyrus strain using the ATTO's densitometer. The relative density of the EAV-specific band was almost in linear proportion for a logarithm of quantity of the virus titer. 


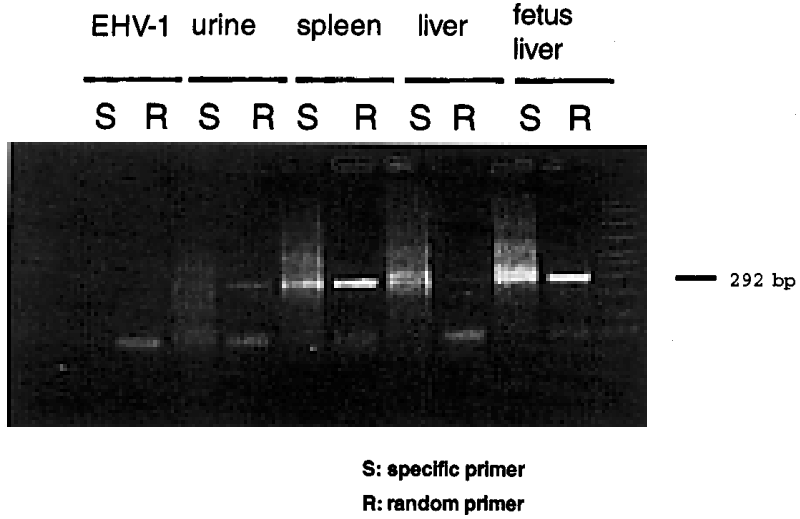

Fig. 1. RT-PCR using the random primer (R) or specific primer (S) for the reverse transcription step. EHV-1 was used as a negative control as described previously [19]. AmpliSize $^{\mathrm{TM}}$ DNA Size standard 50-2,000 bp Ladder (Bio-Rad) was used as a molecular weight standard marker. One band contains $50 \mathrm{ng}$ DNA.

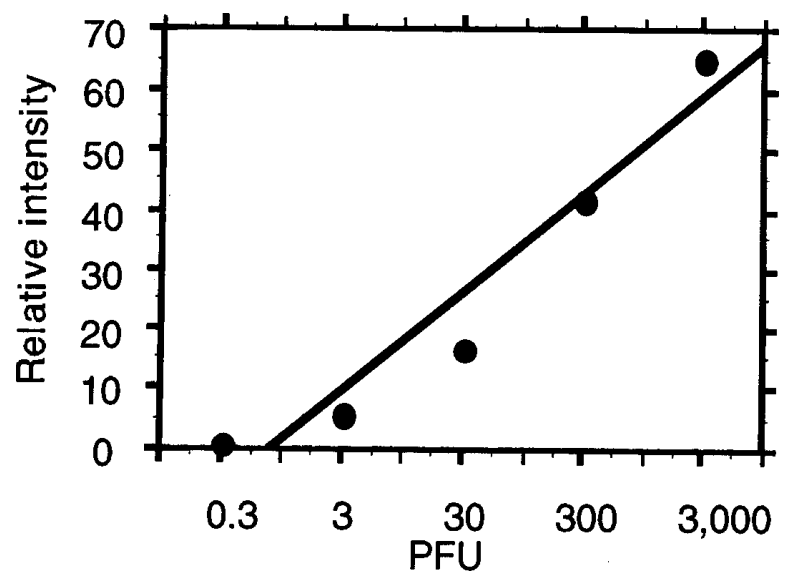

Fig. 2. Density of the band of RT-PCR for modified Bucyrus strain obtained by densitometry. The horizontal axis shows the dose of virus RNA titrated by plaque assay (PFU). The vertical axis shows, the relative density of the EAV-specific $292 \mathrm{bp}$ band.

The PCR detection limits of various strains of EAV were determined by the same method of above analysis. The PCR detection limit for the Bibuna and Vienna strains of EAV was about $100 \mathrm{PFU}$, although that for Bucyrus, modified Bucyrus, 84KY-A1, Red Mile and Vienna strains was 1-10 PFU.

\section{Discussion}

In previous studies the nested PCR method was used
Table 1. Comparison between PCR detection and virus isolation.

\begin{tabular}{|c|c|c|c|}
\hline & Organ & $\begin{array}{c}\text { PCR } \\
\text { detection }\end{array}$ & $\begin{array}{c}\text { Virus } \\
\text { isolation }\end{array}$ \\
\hline \multirow[t]{21}{*}{ Mare } & Lung & ++ & + \\
\hline & Kidneys & ++ & + \\
\hline & Kidney lymph node & ++ & + \\
\hline & Liver & $t^{* * *}$ & $+^{*}$ \\
\hline & Liver lymph node & ++ & + \\
\hline & Spleen & ++ & + \\
\hline & Spleen lymph node & ++ & + \\
\hline & Intestine lymph node & ++ & + \\
\hline & Internal iliac lymph node & ++ & + \\
\hline & Myocardium & + & $+^{*}$ \\
\hline & Submaxillary lymph node & ++ & + \\
\hline & Tonsils & ++ & + \\
\hline & Mammary gland & ++ & + \\
\hline & Uterine muscular tissue & ++ & + \\
\hline & Uterine mucosa & ++ & + \\
\hline & Placenta & ++ & + \\
\hline & Amnion & ++ & + \\
\hline & Feces & - & - \\
\hline & Urine & ++ & $t^{* *}$ \\
\hline & Serum & - & - \\
\hline & Leukocyte & ++ & + \\
\hline \multirow[t]{2}{*}{ Fetus } & Lungs & ++ & + \\
\hline & Liver & ++ & + \\
\hline
\end{tabular}

*Virus could be isolated after secondary passage in cell cultures. **Virus isolation was carried out after dialysis.

***When the cDNA band of the PCR product was weaker than that of the standard marker shown in Fig. 2, + and when stronger, ++.

for the RT-PCR of the EAV [1, 4, 19]. Although the nested PCR method has a very high sensitivity, a false positive band often appeared from the contamination of the 1 st cycle amplified cDNA. To prevent a false positive band, the procedure must be done with expert skill in a safety cabinet and using equipment free from nucleotide contamination must be used. Accordingly, we modified the RT-PCR protocol to obtain a higher sensitivity, we increased the PCR cycles from 30 to 50 without employing the nested PCR protocol.

When the specific primer was used as a primer at the reverse transcription reaction step for various clinical and autopsied tissue samples from horses experimentally infected with EAV, the judgment was difficult because of appearance of the smear band of nonspecific amplified cDNA. To the contrary, when a random primer was used, the clear single positive band, which made judgement easy, was detected. For example, from the liver sample (Fig. 1), a nonspecific band appeared strongly even only a small amount of EAV was isolated (Table 1). We speculate that when the specific primer was used, many specific primer were nonspecifically 
primed to the random place of RNA. Therefore, we employed the random primer for a primer of reverse transcriptional reaction instead of the specific primer owing to a significant decrease of background shown in Fig. 2.

The detection limit of the Bibuna and Vienna strains of EAV was 100 PFU, whereas that of the Bucyrus, modified Bucyrus, 84KY-A1, Red Mile and Wroclaw strains ranged from 1 to $10 \mathrm{PFU}$. The low sensitivities of Bibuna and Vienna strains may be explained by the 1 base mismatch which existed between the F2 or R1 primer and Bibuna or Vienna strain of EAV.

EAV is so polymorphic [20], that it is difficult to find the complete consensus PCR primer set. We must always consider the presence of one point mismatch between the wild strain and primers. In this case, the sensitivity would decrease around $1 / 10-1 / 100$. Since RNA viruses are highly mutatable [20], it is very important to establish a molecular epidemiological observation system to detect the mutation by sequencing of wild pandemic strains.

The densitometric analysis study indicated that the quantity of viral RNA was consistent with the EAV titer, considering an upward linearity relationship between density of PCR band and PFU titer of EAV (Fig. 2). Therefore, the viral titer of the clinical or autopsied tissue materials may be estimated from the result of densitometric analysis of the PCR product.

By this EAV detection method using RT-PCR, the EAV can be detected from clinical and autopsy materials quickly, within 1 day. Furthermore, our method can be suitable for the detection of such a urine sample directly, which has strong toxicity for cell culture and is difficult to isolate the virus without pretreatment. Accordingly, our PCR method is expected to be clinically useful.

\section{References}

1. Belák, S., Ballagi-Pordány, A., Timoney, P.J., McCollum, W.H., Little, T.V., Hyllseth, B. and Klingeborn, B. 1994. Evaluation of a nested PCR assay for the detection of equine arteritis virus. pp. 33-38. In: The 7th International Conference on Equine Infectious Diseases.

2. Bürki, F. 1970. The virology of equine arteritis. pp. 125-129. In: Proc. 2nd Int. Conf. Equine Infectious Diseases.

3. Bürki, F. F. 1965. Eigenschaften des Virus der Equine Arteritis. Path. Microbiol. 28: 939-949.

4. Chirnside, E.D. and Spaan, W.J. 1990. Reverse transcription and cDNA amplification by the polymerase chain reaction of equine arteritis virus (EAV). J. Virol. Methods 30: 133-140.

5. Chirnside, E.D., Wearing, C.M., Binns, M.M. and Mumford, J.A. 1994. Comparison of $\mathrm{M}$ and $\mathrm{N}$ gene sequences distinguishes variation amongst equine arteritis virus isolates. J. Gen. Virol. 75: 1491-1497.

6. Collins, J.K., Kari, S., Ralstone, S.L., Benett, D.G., Traub-Dargantz, J.L. and McKinnon, A.O. 1987. Equine viral arteritis at a veterinary teaching hospital. Prev. Vet. Med. 4: 389-397.

7. Doll, E.R., Bryans, J.T., McCollum, W.H. and Crowe, M.E.W. 1957. Isolation of a filterable agent causing arteritis of horses and abortion by mares: Its differentiations from equine abortion (influenza) virus. Cornell Vet. 47: 3-42.

8. Doll, E.R., Bryans, J.T., Wilson, J.C. and McCollum, W.H. 1968. An outbreak of abortion caused by the equine arteritis virus. Cornell Vet. 47 : 69-75.

9. Doll, E.R., Knapenberger, R.E. and Bryans, J.T. 1957. An outbreak of abortion caused by the equine arteritis virus. Cornell Vet. 47: 69-75.

10. Fukunaga, Y., Imagawa, H., Tabuchi, E. and Akiyama, Y. 1981. Clinical and virological findings on experimental Equine Viral Arteritis in horses. Bull. Equine Res. Inst. 18: 110-118.

11. Fukunaga, Y., Matsumura, T., Sugiura, T., Wada, R., Imagawa, H., Kanemaru, T. and Kamada, M. 1994. Use of the serum neutralisation test for equine viral arteritis with different virus strains. Vet. Rec. 134: 574-576.

12. Fukunaga, Y., Wada, R., Matsumura, T., Anzai, T., Imagawa, H., Sugiura, T., Kumanomido, T., Kanemaru, T. and Kamada, M. 1992. An attempt to protect against persistent infection of Equine Viral Arteritis in the reproductive tract of stallions using formalin inactivated-virus vaccine. pp. 239244. In: The 6th International Conference on Equine Infectious Diseases.

13. Gerber, H., Steck, F., Hofer, B., Walther, L. and Freidli, U. 1978. Serological investigations on equine viral arteritis. pp. 461-465. In: Proc. 4th Int. Conf. Equine Inf. Dis.

14. Golnik, W., Michaska, Z. and Michalak, T. 1981. Natural equine viral arteritis in foals. Schweiz. Arch. Tierheilk 123: 523-533.

15. Golnik, W., Moraillon, A. and Golnik, J. 1986. Identification and antigenic comparison of equine arteritis virus isolated from an outbreak of epidemic abortion of mares. Zentralbl Veterinarmed [B] 33: 413-417. 
16. McCollum, W.H. 1969. Development of a modified virus strain and vaccine for equine viral arteritis. Am. Vet. Med. Ass. 155: 318-322.

17. McCollum, W.H. and Swerczek, T.W. 1978. Studies of an epizootic of equine viral arteritis in racehorses. The Journal of Equine Medicine and Surgey 2: 293-299.

18. Murphy, T.W., Timoney, P.J. and McCollum, W.H. 1988. Analysis of genctic variation among strains of equine arteritis virus. pp. 3-12. In: The 5 th International Conference on Equine Infectious Diseases.
19. Sekiguchi, K., Sugita, S., Fukunaga, Y., Kondo, T., Wada, R., Kamada, M. and Yamaguchi, S. 1995. Detection of equine arteritis virus (EAV) by polymerase chain reaction (PCR) and differentiation of EAV strains by restriction enzyme analysis of PCR products. Arch. Virol. 140: 14831491.

20. Sugita, S., Kondo, T., Sekiguchi, K., Yamaguchi, S., Kamada, M., Nerome, K., and Fukunaga, Y. 1994. Molecular evolution of the $\mathrm{M}$ gene of equine arteritis virus. pp. 39-43. In: The 7th International Conference on Equine Infectious Diseases. 